\title{
PRAKTIK DENDA KETERLAMBATAN PELUNASAN PRODUK PEMBIAYAAN ARRUM HAJI DI PEGADAIAN SYARIAH BLAURAN SURABAYA DALAM TINJAUAN HUKUM ISLAM
}

\author{
Suad Qurrotul Aini \\ Surabaya \\ suadqa@gmail.com
}

\begin{abstract}
This study aims to answer questions about the mechanism for determining penalties for late payment of Arrum Haji financing products at the Blauran Surabaya branch of Sharia Pawnshops and analysis of Islamic law both in fiqh and fatwa DSN MUI no. 43 of 2004. Sharia pawnshops are inseparable from the risk of loss, so that compensation ( $t a^{\prime}$ wid) is enforced. In its implementation, Sharia Pawnshops include the amount of compensation in the contract agreement, while it is stated in the special provisions of Fatwa DSN MUI No. 43 of 2004 concerning Compensation ( $t a^{\prime}$ wid) stating that the amount of compensation may not be included in the contract agreement. The results of this study indicate that the determination of the amount of compensation ( $t a^{\prime}$ wid) is not fully in accordance with the legal requirements of $t a$ 'wid if the losses incurred are not due to real losses and only in the form of losses that are only estimated, as well as regarding penalties for late repayment of financing. or what is known as ta'wid (compensation) according to the fatwa DSN-MUI No. 43 of 2004, this practice is not appropriate because the fatwa is not allowed to state the amount of compensation/fines for losses or damages. customer negligence, but in practice Sharia Pawnshops include the amount of compensation in the contract.
\end{abstract}

Keywords: Late Fines, Fatwa DSN-MUI No. 43 of 2004, Ta'wid

\begin{abstract}
Abstrak: Penelitian ini bertujuan untuk menjawab pertanyaan tentang mekanisme penentuan denda keterlambatan pelunasan produk pembiayaan Arrum Haji di Pegadaian Syariah cabang Blauran Surabaya dan analisis hukum Islamnya baik secara fikih maupun fatwa DSN MUI No. 43 Tahun 2004. Pegadaian Syariah dengan kemunculannya tidak terlepas dari resiko kerugian, sehingga diberlakukannya ganti rugi (tawid). Dalam pelaksanaannya, Pegadaian Syariah mencantumkan jumlah besarnya ganti rugi pada akad perjanjian, sedangkan dinyatakan dalam ketentuan khusus Fatwa DSN MUI No 43 Tahun 2004 tentang Ganti Rugi (ta'wid) menyatakan bahwa besarnya ganti rugi tidak boleh dicantumkan dalam akad perjanjian. Hasil penelitian ini menunjukkan bahwa penentuan besaran ganti rugi (ta'wid) tersebut belum sepenuhnya sesuai dengan syarat sahnya ta'widapabila kerugian yang ditimbulkan bukan karena kerugian yang riil dan hanya berupa kerugian yang hanya diperkirakan saja, serta mengenai denda keterlambatan pelunasan pembiayaan atau yang dikenal sebagai ta'wid(ganti rugi) menurut Fatwa DSN- MUI No 43 Tahun 2004 tentang ta'wid(ganti rugi), praktik tersebut tidak sesuai karena dalam fatwa tersebut tidak diperbolehkan mencantumkan besaran ganti rugi/denda atas
\end{abstract}

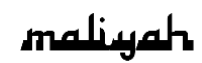

Jurnal Hukum Bisnis Islam

Volume 10, Nomor 01, Juni 2020

p-ISSN: 2088-4869/ e-ISSN: 2597-4351 
Praktik Denda Keterlambatan Pelunasan Produk Pembiayaan Arrum Haji ...

kerugian atau kelalaian nasabah, namun pada praktiknya Pegadaian Syariah mencantumkan besaran ganti rugi tersebut di dalam akad.

Kata Kunci: Denda Keterlambatan, Fatwa Dsn- Mui No 43 Tahun 2004, Ta'wid

\section{Pendahuluan}

Pegadaian Syariah merupakan lembaga keuangan Syariah nonbank yang memiliki beberapa produk berbasis Syariah. Pegadaian Syariah memberikan kemudahan bagi masyarakat untuk mengajukan pinjaman dengan memberikan barang jaminan. Beberapa produk Pegadaian Syariah diantaranya adalah gadai emas, tabungan emas, konsinyasi emas, dan masih banyak lagi.

Salah satu inovasi Pegadaian Syariah terdapat pada produk pembiayaan yaitu pada produk Arrum Haji. Produk ini pertama kali dikeluarkan pada bulan April 2016, dengan maksud dan tujuan agar dapat membantu umat muslim untuk mewujudkan rukun Islam yang kelima, yaitu haji.

Produk Arrum Haji merupakan produk pembiayaan dari Pegadaian Syariah yang memungkinkan nasabah untuk mendapatkan porsi haji dengan jaminan emas seberat 15 gram atau setara dengan sejumlah Rp7.000.000,-. Selanjutnya nasabah mendapatkan pinjaman uang dari Pegadaian Syariah sejumlah Rp25.000.000,- sesuai dengan biaya pendaftaran haji yang ditetapkan oleh Kementerian Agama Republik Indonesia. ${ }^{1}$

Pinjaman yang diberikan oleh Pegadaian Syariah dibayar secara angsuran. Pegadaian Syariah memberikan opsi kepada nasabah yaitu 12, 24, 36, 48, 60 bulan. Biaya pemeliharaan barang jaminan (mu'nah) per bulan yaitu $0,95 \%$ $\mathrm{x}$ nilai taksiran jaminan. Saat nasabah melakukan akad Arrum

\footnotetext{
${ }^{1}$ Besaran jaminan dapat berubah sewaktu-waktu tergantung besaran taksiran harga emas pada saat itu. Namun besaran jaminan emas intinya harus senilai dengan Rp 15.000.000,- yang disyaratkan oleh Pegadaian Syariah.
} 
Haji, maka nasabah sekaligus membuka tabungan haji dan nomor porsi haji. ${ }^{2}$

Produk Arrum Haji menggunakan akad Qard, akad ini berupa pemberian dana yang dipinjamkan kepada nasabah untuk mendapatkan porsi haji, dengan ketentuan nasabah harus mengembalikan dana tersebut dalam jangka waktu tertentu dengan adanya biaya ujrah yang harus dibayarkan kepada Pegadaian Syariah. Selain itu, ada pula akad rahn. Dalam hal ini nasabah memberikan jaminan kepada Pegadaian Syariah sebagai harta yang dititipkan untuk mendapatkan pembiayaan pendaftaran haji. Pegadaian Syariah sebagai murtahin pada akad rahn mendapatkan ujrah sebagai pergantian biaya pemeliharaan barang jaminan yang tidak dibayarkan secara tunai. Hal tersebut sesuai dengan fatwa yang diatur oleh Majelis Ulama Indonesia yang tertera pada Fatwa Dewan Syariah Nasional MUI No. 92/DSN-MUI/IV/2014 tentang pembiayaan yang disertai al-rahn (al Tamwil al Mauthuq bi alrahn). ${ }^{3}$

Dalam pelaksanaan akad rahn dalam produk pembiayaan Arrum Haji, terdapat penerapan ganti rugi. Ganti rugi (ta'wid) diterapkan kepada nasabah yang sengaja atau karena kelalaian melakukan sesuatu yang menyimpang dari akad dan menimbulkan kerugian bagi Pegadaian Syariah.

Kata al ta'widberasal dari iwadha (عوض) yang berarti ganti. ${ }^{4}$ Sedangkan al ta'wid secara bahasa berarti mengganti (rugi) atau membayar kompensasi. Adapun menurut istilah adalah menutup kerugian yang terjadi akibat pelanggaran atau kekeliruan. ${ }^{5}$ Kerugian yang dimaksud adalah kerugian yang menimpa seseorang, baik menyangkut dirinya atau harta

\footnotetext{
${ }^{2}$ Brosur Arrum Haji Pegadaian Syariah, n.d.

${ }^{3}$ Ibid.

${ }^{4}$ Basuni Imamuddin and Nashiroh Ishaq, Kamus Konstektual Arab-Indonesia (Depok: Gema Insani, 2012).420

${ }^{5}$ Wahbah al-Zuhaili, Nazariyah Al-Dhaman (Damsyiq: Dar al-Fikr, 1998).248
} 
kekayaannya, sehingga menimbulkan berkurangnya kualitas, kuantitas, ataupun manfaatnya.

Di Pegadaian Syariah cabang Blauran, ta'widdikenakan kepada nasabah yang telat melakukan pembayaran sejak $\mathrm{H}+1$ dari tanggal jatuh tempo tanpa mengetahui alasan nasabah terlebih dahulu. Ketentuan mengenai ta'wid dicantumkan dalam akad dengan besaran nilai ta'wid sudah diketahui sejak awal akad. Pegadaian Syariah menetapkan ganti rugi (ta'wid) pada produk baru Arrum Haji berdasarkan keterlambatan pembayaran atau jangka waktu perhari sebesar 4\% dibagi 30 dari besarnya angsuran tiap bulan. Sedangkan Fatwa DSN MUI dengan jelas menyebutkan bahwa pemberian ganti rugi (ta'wid) itu tidak boleh dicantumkan pada akad dan kerugian itu harus berdasarkan kerugian yang riil, yang dapat diperhitungkan dengan jelas dan bukan kerugian yang diperkirakan akan terjadi.

Jenis penelitan ini adalah penelitian lapangan, yaitu penelitian yang berdasarkan kejadian nyata yang terjadi di masyarakat. ${ }^{6}$ Maka dalam hal ini objek penelitiannya adalah mekanisme penentuan denda atas keterlambatan pelunasan produk pembiayaan Arrum Haji di Pegadaian Syariah cabang Blauran. Data dan sumber data yang digunakan dalam penelitian ini adalah sebagai berikut:

1. Sumber Primer

Sumber primer adalah yang memberi informasi langsung kepada pengumpul data, dan cara pengumpulannya dapat dilakukan dengan interview atau wawancara, dokumentasi, dan gabungan dari keduanya. ${ }^{7}$ Wawancara dilakukan kepada nasabah yang pernah melakukan pembiayaan Arrum Haji di Pegadaian Syariah cabang Blauran Surabaya, manager Pegadaian Syariah cabang

\footnotetext{
${ }^{6}$ Mukti Fajar, Desain Penelitian Hukum Normatif Dan Empiris (Yogyakarta: Pustaka Pelajar, 2010). 159

${ }^{7}$ Andi Prastowo, Metode Penelitian Kualitatif (Yogyakarta: Ar-Ruzz Media, 2014). 211
} 
Blauran Surabaya, serta staff dan pegawai Pegadaian Syariah cabang Blauran Surabaya.

2. Sumber Sekunder

Sumber data sekunder adalah yang tidak bisa memberi informasi secara langsung pada pengumpul data seperti lewat dokumen, orang lain, dan sebagainya.

Teknik pengumpulan data yang digunakan dalam penelitian ini adalah sebagai berikut:

1. Wawancara

Dalam penelitian ini, peneliti menggunakan teknik wawancara yaitu pengumpulan data yang dilakukan dengan berhadapan secara langsung dengan diwawancarai tetapi dapat juga diberikan daftar pertanyaan dahulu untuk dijawab pada kesempatan lain. ${ }^{8}$ Metode ini dilakukan dalam rangka memperoleh data atau informasi dari nasabah yang pernah melakukan keterlambatan pembayaran pembiayaan Arrum Haji. Dan melalui wawancara tersebut penulis berharap dapat memberikan informasi tambahan yang mendukung data utama yang telah diperoleh dari sumber primer. Adapun narasumber yang dipilih untuk diwawancari dalam penelitian ini adalah sebagai berikut:

a. Nasabah yang pernah melakukan pembiayaan Arrum Haji di PegadaianSyariah cabang Blauran Surabaya.

Nasabah pembiayaan Arrum Haji menjadi salah satu responden yang dipilih untuk memberikan informasi guna keabsahan data pada penelitian ini. Dalam hal ini nasabah yang dibutuhkan adalah nasabah yang telah atau sudah mengikuti pembiayaan Arrum Haji, serta nasabah yang pernah atau sedang melakukan keterlambatan pembayaran angsuran setiap bulannya, sehingga dapat memberikan data mengenai denda keterlambatan sesuai dengan objek penelitian.

b. Manager Pegadaian Syariah cabang Blauran Surabaya

8 Juliansyah Noor, Metodologi Penelitian (Jakarta: Prenadamedia Group, 2015). 138 
Manager Pegadaian Syariah cabang Blauran dipilih menjadi salah satu responden untuk dapat memberikan penjelasan mengenai keseluruhan mekanisme yang ada di Pegadaian Syariah cabang Blauran, memberikan informasi mengenai produk-produk yang ada di Pegadaian Syariah cabang Blauran beserta mekanismenya, serta memberikan data serta izin penelitian yang dibutuhkan dalam penelitian ini.

c. Staff dan Pegawai Pegadaian Syariah cabang Blauran Surabaya

Dalam hal ini staff yang dibutuhkan yaitu Customer Service (CS) dan Kasir. Customer Service (CS) dipilih menjadi salah satu responden dikarenakan adanya hubungan langsung kepada nasabah. Customer Service (CS) melakukan hubungan langsung dengan nasabah dalam hal akad pembiayaan Arrum Haji serta pengurusan pendaftaran ibadah Haji, sedangkan Kasir melakukan hubungan langsung dengan nasabah saat melakukan angsuran setiap bulannya.

2. Dokumentasi

Dokumentasi merupakan sejumlah besar fakta dan data tersimpan dalam bahan yang berbentuk dokumentasi. Sebagian besar data yang tersedia yaitu berbentuk surat, brosur, surat permohonan, laporan, dan foto. ${ }^{9}$ Adapun sebagai pelengkapan dalam pengumpulan data maka penulis menggunakan data dari sumber-sumber terkait dengan kajian yang dibahas misalnya buku, internet, jurnal dan lain sebagainya.

\section{Pengertian ta'wid}

Kata al-ta'widberasal dari kata iwada yang berarti memberi ganti, sedangkan al-ta'wid secara Bahasa berarti mengganti (rugi) atau membayar kompensasi. ${ }^{10 ~ " T a ' w i d(g a n t i ~}$ rugi) adalah menutup kerugian yang terjadi akibat

\footnotetext{
${ }^{9}$ Ibid. 141

${ }^{10}$ Tim Kashiko, Kamus Lengkap Arab Indonesia (Surabaya: Kashiko, 2000).449
} 
pelanggaran atau kekeliruan" 11 Secara umum pengertian ta'wid adalah menutup kerugian yang terjadi dikarenakan adanya pelanggaran atau kekeliruan dengan adanya ketentuan terdapat kerugian riil yang dapat diperhitungkan dengan jelas dalam suatu perjanjian tersebut dengan upaya untuk memperoleh pembayaran dan bukan merupakan kerugian yang diperkirakan akan terjadi karena adanya peluangan yang hilang. ${ }^{12}$

Menurut Kompilasi Hukum Ekonomi Syariah (KHES), ganti rugi merupakan suatu sanksi berupa pembayaran ganti rugi/pembatalan akad/peralihan risiko oleh salah satu pihak tidak melaksanakan apa yang sudah diperjanjikan. ${ }^{13} \mathrm{Hal}$ tersebut sesuai dengan Kompilasi Hukum Ekonomi Syariah (KHES) padal 36 dan 38, yang berbunyi:

Pasal 36

"Pihak dapat dianggap melakukan ingkar janji, apabila karena kesalahannya:

a. Tidak melakukan apa yang dijanjikan untuk melakukannya;

b. Melaksanakan apa yang dijanjikannya, tetapi tidak sebagaimana dijanjikan;

c. Melakukan apa yang dijanjikannya, tetapi terlambat; atau

d. Melakukan sesuatu yang menurut perjanjian tidak boleh dilakukan. ${ }^{14}$

Pasal 38

Pihak dalam akad yang melakukan ingkar janji dapat dijatuhi sanksi:

\footnotetext{
${ }^{11}$ Wahbah Al-Zuhaili and Adiwarman A. dalam Karim, Maqashid Bisnis Dan Keuangan Islam: Sintesis Fikih Dan Ekonomi (Jakarta: Rajawali Pers, 2016). 156

${ }^{12}$ Samnur Abdullah, "Mekanisme Penetapan Ta'widh Di Bank BNI Syariah Pada Produk Hasanah Card" (Skripsi S1 FSH UIN Syarif Hidayatullah Jakarta, 2012). 90

${ }^{13}$ Fokusmedia, Kompilasi Hukum Ekonomi Syariah (Bandung: Fokusmedia, 2008). 22

14 Ibid.
} 
a. Membayar ganti rugi.

b. Pembatalan akad;

c. Peralihan risiko;

d. Denda; dan/atau

e. Membayar biaya perkara. ${ }^{15}$

Menurut prinsip umum syariah, diperbolehkan meminta suatu ganti rugi apabila terdapat kerugian atau kerusakan dari pihak lawan secara wajar. Lembaga keuangan harus mempertimbangkan perolehan jaminan dalam suatu kontrak atau perjanjian yang telah disepakati. Maka ketika kerugian atau kerusakan tersebut timbul karena suatu kesalahan pelanggan (nasabah), masuk akal bila sebuah lembaga keuangan meminta sebuah ganti rugi dari pelanggan (nasabah) tersebut. $^{16}$

Namun besarnya ganti rugi yang harus dibayar oleh nasabah harus sesuai dengan kerugian riil (real loss) dan kerugian tersebut sudah pasti dialami (fixed cost) dalam sebuah transaksi. Jadi tidak berupa perkiraan kerugian yang akan terjadi karena adanya sebuah peluang yang hilang. ${ }^{17}$

\section{Dasar Hukum Ta'wid}

1. Al-Qur'an

Q.S. al-Ma'idah ayat 1

"Hai orang-orang yang beriman, penuhilah akad-akad itu".18

Maksud dari ayat tersebut menjelaskan bahwa setiap orang harus memenuhi sesuatu yang telah diperjanjikan tanpa adanya penundaan dalam pembayaran apabila dalam keadaan mampu, serta janganlah merugikan pihak lain

\footnotetext{
${ }^{15}$ Ibid.22-23

${ }^{16}$ International Shari'ah Research Academy for Islamic Finance (ISRA), Sistem Keuangan Islam: Prinsip Dan Operasi, Terj. Ellys T (Jakarta: RajaGrafindo Persada, 2015).290

17 Fatwa DSN MUI Nomor 43 Tahun 2004 Tentang Ganti Rugi, n.d.

18 Departemen Agama Republik Indonesia, Al-Qur'an Dan Terjemahannya (Bandung: Syamiil al-Qur'an, 2005).84
}

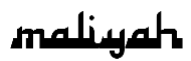

Jurnal Hukum Bisnis Islam 
dalam hal transaksi. Apabila terjadi kerugian dibalas dengan kerugian yang dapat diterima.

Q.S. al-Isra' ayat 34

"Dan penuhilah janji; Sesungguhnya janji itu pasti diminta pertanggungjawabnya". ${ }^{19}$

Dalam ayat tersebut Allah memerintahkan umat manusia agar memenuhi janji, baik berupa perjanjian kepada Allah maupun sesama manusia. Perjanjian yang telah disepakati harus dilaksanakan sesuai hukum dan aturan yang berlaku, sehingga apabila terdapat pihak yang melanggar maka akan mendapatkan balasan yang setimpal.

2. Hadis $^{20}$

Hadis Nabi riwayat Tirmizi dari 'Amr bin 'Auf:

"Perjanjian boleh dilakukan di antara kaum muslimin kecuali perjanjian yang mengharamkan yang halal atau menghalalkan yang haram; dan kaum muslimin terikat dengan syarat-syarat mereka kecuali syarat yang mengharamkan yang halal atau menghalalkan yang haram".

3. Kaidah Fikih

"Hukum asal segala sesuatu adalah kebolehan sampai ada dalil yang menunjukkan keharamannya". ${ }^{21}$

\section{Fatwa dan Fatwa DSN MUI Nomor 43 Tahun 2004}

Dewan Syariah Nasional Majelis Ulama Indonesia (DSNMUI) dalam fatwa 43 tahun 2004 tentang ta'wid (Ganti Rugi) memutuskan beberapa point yaitu diantaranya:

Pertama : Ketentuan Umum

1. Ganti rugi (ta'wid) hanya boleh dikenakan atas pihak yang dengan sengaja atau karena kelalaian melakukan sesuatu yang menyimpang dari ketentuan akad dan menimbulkan kerugian pada pihak lain.

${ }^{19}$ Ibid.327

${ }^{20}$ Fatwa DSN MUI Nomor 43 Tahun 2004 Tentang Ganti Rugi.

21 A. Djazuli, Kaidah-Kaidah Fiqih: Kaidah-Kaidah Hukum Islam Dalam Menyelesaikan Masalah- Masalah Yang Praktis, Cet.1 (Jakarta: Kencana, 2006). 51 
2. Kerugian yang dapat dikenakan ta'widadalah kerugian riil yang dapat diperhitungkan dengan jelas.

3. Kerugian riil adalah biaya-biaya riil yg dikeluarkan dalam rangka penagihan hak yg seharusnya dibayarkan.

4. Besar ganti rugi (ta'wid) adalah sesuai dengan nilai kerugian riil (real loss) yang pasti dialami (fixed cost) dalam transaksi tersebut dan bukan kerugian yang diperkirakan akan terjadi (potential loss) karena adanya peluang yang hilang (opportunity loss atau al-furshah aldha-i'ah).

5. Ganti rugi (ta'wid) hanya boleh dikenakan pada transaksi (akad) yang menimbulkan utang piutang (dain), seperti salam, istishna' serta murabahah dan ijarah.

6. Dalam akad Mudharabah dan Musyarakah, ganti rugi hanya boleh dikenakan oleh shahibul mal atau salah satu pihak dalam musyarakah apabila bagian keuntungannya sudah jelas tetapi tidak dibayarkan.

Kedua : Ketentuan Khusus

1. Ganti rugi yang diterima dalam transaksi di LKS dapat diakui sebagai hak (pendapatan) bagi pihak yang menerimanya.

2. Jumlah ganti rugi besarnya harus tetap sesuai dengan kerugian riil dan tata cara pembayarannya tergantung kesepakatan para pihak.

3. Besarnya ganti rugi ini tidak boleh dicantumkan dalam akad.

4. Pihak yang cedera janji bertanggung jawab atas biaya perkara dan biaya lainnya yang timbul akibat proses penyelesaian perkara.

Ketiga: Penyelesaian Perselisihan

Jika salah satu pihak tidak menunaikan kewajibannya atau terjadi perselisihan di antara kedua belah pihak, maka penyelesaiaannya dilakukan melalui Badan Arbitrase Syari'ah setelah tidak tercapai kesepakatan melalui musyawarah

Keempat : Ketentuan Penutup 
Fatwa ini berlaku sejak tanggal ditetapkan dengan ketentuan, jika di kemudian hari ternyata terdapat kekeliruan, akan diubah dan disempurnakan sebagaimana mestinya.

\section{Mekanisme Penentuan Denda Pada Produk Pembiayaan Arrum Haji Di Pegadaian Syariah Cabang Blauran Surabaya}

ARRUM haji merupakan salah satu produk yang dikeluarkan oleh Pegadaian Syariah Cabang Blauran yang diperuntukkan bagi nasabah yang akan menunaikan ibadah haji, dalam hal ini Pegadaian Syariah Cabang Blauran membantu nasabah agar dapat melaksanakan ibadah haji dengan menggadaikan emas atau logam mulia seberat 15 gram atau senilai dengan Rp 7.000.000, nasabah akan segera mendapatkan porsi haji dengan Pegadaian Syariah memberikan pinjaman uang sebesar Rp 25.000.000 dalam bentuk tabungan haji. ${ }^{22}$

Menurut Ibu Wuwuh A, produk pembiayaan Arrum Haji ini cukup diminati oleh masyarakat, hal tersebut dibuktikan dengan jumlah nasabah yang tercatat menggunakan produk pembiayaan Arrum Haji hingga akhir tahun 2018 ini tercatat ada 84 orang nasabah yang mendaftar di Pegadaian Syariah Cabang Blauran Surabaya. ${ }^{23}$ Berikut adalah rincian daftar nasabah Arrum Haji di Pegadaian Syariah Cabang Blauran Surabaya periode 2016-2018:

Tabel 3.1 Daftar nasabah Arrum Haji di Pegadaian Syariah Cabang Blauran Surabaya periode 2016-2018

\begin{tabular}{|c|l|c|c|}
\hline No & Bulan Akad & Tahun Akad & Jumlah Nasabah \\
\hline 1. & Mei & 2016 & 2 \\
\hline 2. & Juli & 2016 & 7 \\
\hline 3. & Mei & 2017 & 2 \\
\hline 4. & Juni & 2017 & 5 \\
\hline
\end{tabular}

22 “Https://Pegadaiansyariah.Co.Id/Arrum-Haji-45162.”diakses tgl 20 Mei 2019 ${ }^{23}$ Wuwuh, Asisten Manager Cabang, Wawancara, Surabaya 15 Mei 2019 
Praktik Denda Keterlambatan Pelunasan Produk Pembiayaan Arrum Haji ...

\begin{tabular}{|c|l|c|c|}
\hline 5. & Juli & 2017 & 5 \\
\hline 6. & Oktober & 2017 & 6 \\
\hline 7. & November & 2017 & 5 \\
\hline 8. & Januari & 2018 & 2 \\
\hline
\end{tabular}

\begin{tabular}{|c|l|c|c|}
\hline 9. & Februari & 2018 & 2 \\
\hline 10. & Maret & 2018 & 2 \\
\hline 11. & April & 2018 & 6 \\
\hline 12. & Mei & 2018 & 13 \\
\hline 13. & Juli & 2018 & 3 \\
\hline 14. & Agustus & 2018 & 7 \\
\hline 15. & September & 2018 & 4 \\
\hline 16. & Oktober & 2018 & 5 \\
\hline 17. & November & 2018 & 5 \\
\hline 18. & Desember & 2018 & 3 \\
\hline \multicolumn{3}{|c|}{ Jumlah } & 84 \\
\hline
\end{tabular}

Adapun persyaratan yang harus dipenuhi oleh nasabah yang mengajukan pembiayaan Arrum Haji adalah sebagai berikut: 24

1. Beragama Islam.

2. Berusia minimal 12 (dua belas) tahun pada saat mendaftar.

3. Memiliki KTP yang masih berlaku sesuai domisili atau identitas lain yang sah.

4. Memiliki kartu keluarga.

5. Memiliki akte kelahiran atau surat kenal lahir atau kutipan akta nikah atau ijasah.

6. Usia rahin pada saat jatuh tempo adalah 60 (enam puluh) tahun.

7. Memiliki pas foto terbaru ukuran $3 \times 4 \mathrm{~cm}$ sebanyak 10 (sepuluh) lembar.

Adapun proses yang harus dilakukan oleh nasabah untuk mendapatkan pembiayaan Arrum Haji di Pegadaian Syariah Blauran adalah sebagai berikut:

Gambar 3.1 Alur Pembiayaan Arrum Haji

\footnotetext{
${ }^{24}$ Hapsari Wijaya, Customer Service, Wawancara, Surabaya 15 Mei 2019
} 


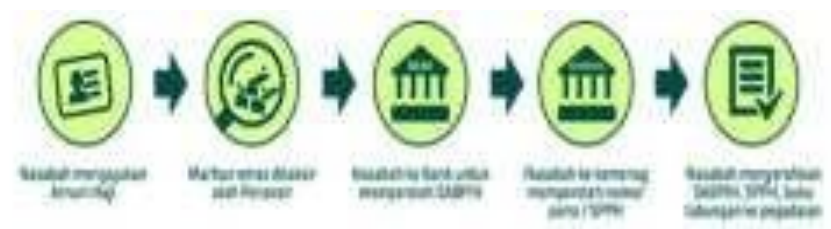

Keterangan: ${ }^{25}$

1. Nasabah mengajukan permohonan pembiayaan ARRUM haji dengan menyertakan persyaratan-persyaratan yang sudah ditetapkan oleh pihak Pegadaian.

2. Nasabah menyerahkan jaminan berupa uang senilai Rp. 7.000.000 atau emas seberat 15 gram yang nantinya emas tersebut akan ditaksir oleh pihak penaksir di Pegadaian Syariah.

3. Nasabah pergi ke Bank untuk memperoleh SABPIH (Setoran Awal Biaya Penyelenggaraan Ibadah Haji) serta pemberian pinjaman yang langsung dikreditkan ke dalam buku tabungan nasabah. Dalam hal ini nasabah akan ditemani oleh pegawai Pegadaian Syariah menuju bank terdekat. Adapun bank yang bekerja sama dengan Pegadaian Syariah Cabang Blauran Surabaya adalah Bank BNI Syariah, Bank BRI Syariah, Bank Mega Syariah.

4. Nasabah mendatangi kemenag untuk mendaftarkan diri sebagai calon jamaah haji dan memperoleh nomor porsi haji/SPPH.

5. Nasabah menyerahkan SABPIH, SPPH dan buku tabungan ke Pegadaian Syariah. Kemudian dilanjutkan dengan pembayaran angsuran sesuai dengan akad yang dilakukan.

Berikut ini adalah proses pada saat awal akad sampai pengembalian seluruh pinjaman oleh nasabah yang diberikan oleh pihak Pegadaian Syariah Cabang Blauran Surabaya:26

1. Biaya pada saat awal akad

Biaya yang harus dikeluarkan oleh nasabah pada saat awal akad yaitu:

25 "Pegadaian Syariah," https://pegadaiansyariah.co.id/.

${ }^{26}$ Hapsari Wijaya, Customer Service, Wawancara, Surabaya 15 Mei 2019 
a. Biaya administrasi sebesar Rp. 270.000

b. Biaya setoran awal sebesar Rp. 500.000, setoran awal ini akan digunakan untuk pembukuan tabungan haji di bank yang sudah bekerja sama dengan Pegadaian Syariah Cabang Blauran Surabaya.

c. Imbal Jasa Kafalah (IJK) adalah biaya atau upah yang dibebankan kepada nasabah untuk keperluan asuransi. Besar Imbal Jasa Kafalah tersebut tergantung dari jangka waktu yang diambil oleh nasabah.

Tabel 3.2 Besaran Imbal Jasa Kafalah

\begin{tabular}{|c|c|c|c|c|}
\hline $\begin{array}{l}\text { Jangka } \\
\text { Waktu }\end{array}$ & $\begin{array}{c}\text { Biaya } \\
\text { Administrasi }\end{array}$ & $\begin{array}{l}\text { Setoran } \\
\text { Pembukua } \\
\text { n }\end{array}$ & IJK & Jumlah \\
\hline 12 bulan & Rp 260.000 & Rp 500.000 & Rp 70.000 & $\operatorname{Rp} 840.000$ \\
\hline 24 bulan & Rp 260.000 & $\operatorname{Rp} 500.000$ & Rp 112.500 & $\operatorname{Rp} 882.500$ \\
\hline 36 bulan & Rp 260.000 & Rp 500.000 & Rp 175.000 & Rp 945.000 \\
\hline 48 bulan & Rp 260.000 & Rp 500.000 & Rp 265.000 & $\operatorname{Rp} 1.035 .000$ \\
\hline 60 bulan & Rp 260.000 & Rp 500.000 & Rp 412.000 & Rp 1.182.500 \\
\hline
\end{tabular}

Sumber : disarikan dari data Arrum Haji 2017

2. Biaya angsuran per bulan dan tahun

Biaya yang harus dikeluarkan oleh nasabah per bulan dan pertahunnya yaitu sebagai berikut:

a. Angsuran pokok yaitu biaya yang harus dikeluarkan oleh nasabah yang besarnya disesuaikan dengan jangka waktu yang telah diambil oleh nasabah.

b. Mu'nah adalah biaya yang dikeluarkan oleh nasabah untuk keperluan pemeliharaan barang jaminan atau biaya atas penjagaan barang jaminan. Dalam pelaksanaan produk ARRUM Haji, nasabah dibebankan untuk membayar mu'nah (biaya pemeliharaan barang jaminan). Besar mu'nah yang 
akan dibayar oleh nasabah sebesar Rp. 252.806 per bulan. Untuk perhitungan mu'nah sendiri yaitu sebagai berikut:

\section{$0.95 \%$ x taksiran $\mathrm{x}$ jangka waktu}

Berikut ini adalah rincian biaya yang harus dibayar setiap bulannya: ${ }^{27}$

Tabel 3.3 Rincian Biaya Bulanan

\begin{tabular}{|c|c|c|c|c|}
\hline $\begin{array}{c}\text { Jangka } \\
\text { waktu }\end{array}$ & $\begin{array}{c}\text { Angsuran } \\
\text { Pokok }\end{array}$ & Mu'nah & $\begin{array}{c}\text { Jumlah } \\
\text { Angsuran } \\
\text { per Bulan }\end{array}$ & $\begin{array}{c}\text { Jumlah } \\
\text { Angsuran } \\
\text { per Tahun }\end{array}$ \\
\hline 12 bulan & Rp 2.083.394 & Rp 252.806 & Rp 2.336.200 & Rp 28. 034.400 \\
\hline 24 bulan & Rp 1.041.794 & Rp 252.806 & Rp 1.294.500 & Rp 31.070.400 \\
\hline 36 bulan & Rp 694.494 & Rp 252.806 & Rp 947.300 & Rp 36.102.800 \\
\hline 48 bulan & Rp 520.894 & Rp 252.806 & Rp 773.700 & Rp 37.137.600 \\
\hline 60 bulan & Rp 416.794 & Rp 252.806 & Rp 669.500 & Rp 40.176.000 \\
\hline
\end{tabular}

Sumber : disarikan dari data ARRUM Haji 2017

Layaknya produk pembiayaan pada umumnya, produk pembiayaan ARRUM Haji pun tidak luput dari adanya kendala atau resiko. Menurut Asisten Manager Cabang, adapun resiko yang paling sering dialami oleh pihak Pegadaian Syariah Cabang Blauran Surabaya yaitu adanya nasabah yang terlambat mengangsur atau nasabah meninggal dunia. ${ }^{28}$ Apabila nasabah tersebut meninggal dunia maka ahli warisnya berhak untuk mengambil alih pembiayaan tersebut sesuai dengan ketentuan dari Pegadaian Syariah. Tetapi apabila nasabah terlambat membayar angsuran setiap bulan pada jatuh tempo yang telah

${ }^{27}$ Hapsari Wijaya, Customer Service, Wawancara, Surabaya 15 Mei 2019

${ }^{28}$ Wuwuh, Asisten Manager Cabang, Wawancara, Surabaya 15 Mei 2019 
ditentukan, maka Pegadaian Syariah Cabang Blauran memberikan ta'wid (denda) kepada nasabah. Dana ta'wid tersebut dipisahkan dengan dana lainnya yang kemudian digunakan untuk Dana Kebajikan Umat (DKU). Adapun perhitungan ta'wid per hari adalah:

$\frac{4 \% \text { cicilan pokok perbulan } \quad h \text { per bulan }}{30}$

\section{Analisis Hukum Islam dan Fatwa DSN MUI No 43 Tahun 2004 Terhadap Denda Keterlambatan Pelunasan Pembiayaan Arrum Haji di Pegadaian Syariah Blauran Surabaya}

Pegadaian Syariah merupakan sebuah lembaga yang kegiatan operasionalnya berlandaskan pada prinsip-prinsip syariah, sebagaimana telah diketahui bahwa setiap produk yang berbasis syariah tentunya memiliki karakteristik yang haruslah terhindar dari riba. Oleh karena itu, dalam kegiatan operasionalnya setiap produk yang ada di Pegadaian Syariah cabang Blauran Surabaya memiliki payung hukum serta mendapatkan pengawasan dari Dewan Syariah Nasional (DSN) dan juga Otoritas Jasa Keuangan (OJK).

Mekanisme operasional Pegadaian Syariah dapat digambarkan melalui akad rahn, nasabah menyerahkan barang bergerak dan kemudian Pegadaian menyimpan dan merawatnya di tempat yang telah disediakan oleh Pegadaian. Akibat yang timbul dari proses penyimpanan adalah timbulnya biaya-biaya yang meliputi nilai investasi tempat penyimpanan, biaya perawatan, dan keseluruhan proses kegiatannya. Atas dasar ini maka dibenarkan bagi Pegadaian mengenakan biaya sewa kepada nasabah sesuai jumlah yang disepakati oleh kedua belah pihak. ${ }^{29}$

Pada dasarnya setiap akad atau perjanjian yang disepakati oleh nasabah dan Pegadaian Syariah dapat

\footnotetext{
${ }^{29}$ Nurul Huda, Lembaga Keuangan Islam (Jakarta: Kencana, 2013).280
} 
dilaksanakan sesuai dengan kesepakatan bersama atau dengan itikad yang baik, namun kenyatannya akad sering kali dilanggar oleh salah satu pihak, dalam hal ini nasabah. Hal tersebut harus diselesaikan agar tidak ada pihak yang dirugikan. Oleh karena itu, Pegadaian Syariah berhak memberikan sanksi bagi nasabah yang tidak atau terlambat melakukan pembayaran pinjaman agar tidak memberikan mudarat bagi semua pihak kecuali apabila nasabah mengalami force majeure.

Dalam ayat tersebut dapat dinyatakan bahwa jika pihak yang berhutang tersebut berada dalam kesukaran, maka berilah dia waktu jatuh tempo hingga dia sanggup membayar hutangnya. Sebaliknya, apabila yang berhutang berada dalam keadaan lapang, maka ia wajib membayar hutangnya. Begitu juga apabila nasabah terlambat dalam membayar angsuran pembiayaan Arrum Haji maka pihak Pegadaian Syariah selain mengingatkan kembali agar nasabah segera mengangsurnya kembali, terdapat adanya denda (ta'wid) yang harus dipenuhi oleh nasabah ditambah dengan angsuran pokok per bulan, dengan perhitungan denda yang dibebankan kepada nasabah yang terlambat membayar sebagai berikut:

$\frac{4 \% \text { cicilan pokok perbulan } \quad h \text { per bulan }}{30}$

Penentuan besaran ganti rugi (ta'wid) tersebut belum sepenuhnya sesuai dengan syarat sahnya ta'wid apabila kerugian yang ditimbulkan bukan karena kerugaian yang riil dan hanya berupa kerugian yang hanya diperkirakan saja sebenarnya tidak tepat untuk dimintai ta'widkarena kerugian tersebut belum pasti dialami dan belum bisa diperhitungkan dengan jelas.

Berdasarkan hasil wawancara yang telah dilakukan, pihak Pegadaian Syariah Cabang Blauran Surabaya yakni yag diwakili oleh ibu Wuwuh A. selaku Asisten Manager cabang di Pegadaiaan Syariah Cabang Blauran Surabaya, di dalam produk Arrum Haji ini menggunakan akad rahn dan juga terdapat ta'wid (ganti rugi) yang ditetapkan bagi nasabah yang 
melakukan keterlambatan pelunasan pembiayaan Arrum Haji di Pegadaian Syariah cabang Blauran.

Dalam produk pembiayaan Arrum Haji yang ada di Pegadaian Syariah cabang Blauran Surabaya ini dibentuk berdasarkan fatwa DSN-MUI yaitu fatwa Nomor 92/DSNMUI/IV/2014 tentang pembiayaan yang disertai rahn (al Tamlik al - Mautsuq bi al - Rahn). Sedangkan fatwa DSN-MUI nomor 43 Tahun 2004 tentang ta'wid (Ganti Rugi) menjadi landasan ditetapkannya denda atas keterlambatan pelunasan pembiayaan Arrum Haji di Pegadaian Syariah cabang Blauran.

Dalam fatwa DSN-MUI nomor 43 Tahun 2004 tentang ta'wid (Ganti Rugi), ketentuan mengenai ta'wid (ganti rugi) adalah sebagai berikut:

1. Ganti rugi (ta'wid) hanya boleh dikenakan atas pihak yang dengan sengaja atau karena kelalaian melakukan sesuatu yang menyimpang dari ketentuan akad dan menimbulkan kerugian pada pihak lain.

2. Kerugian yang dapat dikenakan ta'wid adalah kerugian riil yang dapat diperhitungkan dengan jelas.

3. Kerugian riil adalah biaya-biaya riil yg dikeluarkan dalam rangka penagihan hak yg seharusnya dibayarkan.

4. Besar ganti rugi (ta'wid) adalah sesuai dengan nilai kerugian riil (real loss) yang pasti dialami (fixed cost) dalam transaksi tersebut dan bukan kerugian yang diperkirakan akan terjadi (potential loss) karena adanya peluang yang hilang (opportunity loss atau al-furshah aldhai'ah).

5. Ganti rugi (tawidh) hanya boleh dikenakan pada transaksi (akad) yang menimbulkan utang piutang (dain), seperti salam, istishna' serta murabahah dan ijarah.

6. Dalam akad mudarabahdan musharakah, ganti rugi hanya boleh dikenakan oleh shahibul mal atau salah satu pihak dalam musyarakah apabila bagian keuntungannya sudah jelas tetapi tidak dibayarkan. Selain itu, terdapat ketentuan khusus pada ayat kedua fatwa DSN-MUI nomor 43 Tahun 2004 tentang Ta'widh (Ganti Rugi) yang menyebutkan bahwa: 
a. Ganti rugi yang diterima dalam transaksi di LKS dapat diakui sebagai hak (pendapatan) bagi pihak yang menerimanya.

b. Jumlah ganti rugi besarnya harus tetap sesuai dengan kerugian riil dan tata cara pembayarannya tergantung kesepakatan para pihak.

c. Besarnya ganti rugi ini tidak boleh dicantumkan dalam akad.

d. Pihak yang cedera janji bertanggung jawab atas biaya perkara dan biaya lainnya yang timbul akibat proses penyelesaian perkara.

Menurut fatwa DSN-MUI nomor 43 Tahun 2004 tentang ta'wid (Ganti Rugi) yang disebutkan dalam ketentuan khusus poin ketiga menyatakan bahwa besarnya akad tidak boleh dicantumkan dalam akad. Jadi dalam ketentuan akad yang disepakati antara nasabah dan Pegadaian Syariah tidak boleh mencantumkan perhitungan denda yang harus dibayarkan oleh nasabah apabila ia melakukan keterlambatan pelunasan pembiayaan. Sesuai dengan poin kedua bahwa jumlah ganti rugi yang besarnya harus tetap dan sesuai dengan kerugian riil yang dialami oleh pihak Pegadaian Syariah selaku pihak yang dirugikan, bukan karena kerugian yang hanya diperkirakan dan nantinya akan bertambah terus menerus sehingga menimbulkan kerugian bagi nasabah. Sedangkan pada praktiknya di Pegadaian Syariah Cabang Blauran menyantumkan besaran denda sebesar 4\% dibagi 30 hari dari besaran angsuran tiap bulan dalam akad yang harus disepakati oleh nasabah yang akan melakukan pembiayaan Arrum Haji di Pegadaian Syariah cabang Blauran.

Jika dilihat dari segi kekuatan hukum, fatwa merupakan jawaban hukum yang sejatinya tidak bersifat mengikat. Pada umumnya fatwa hanya dikeluarkan sebagai jawaban atas suatu pertanyaan yang muncul dimana merupakan suatu peristiwa atau suatu permasalahan yang telah terjadi secara nyata sebelumnya. Pihak yang meminta suatu fatwa, baik perorangan, suatu lembaga, maupun masyarakat luas tidaklah harus mengikuti isi atau hukum yang telah diberikan kepada 
mereka. Hal ini disebabkan karena fatwa tersebut tidaklah mengikat sebagaimana putusan pengadilan. Namun demikian, apabila fatwa diadopsi keputusan Pengadilan, maka ia haruslah memiliki kekuatan hukum yang mengikat. ${ }^{30}$

Dalam menyikapi hal tersebut meskipun fatwa DSN-MUI memiliki kekuatan hukum yang masih belum mengikat, penulis tetap sejalan dengan ketentuan yang tercantum di dalam fatwa DSN-MUI yaitu fatwa Nomor 43/DSN-MUI/VIII/2004 tentang Ta'wid(Ganti Rugi) yang menjelaskan bahwa besarnya ganti rugi ini tidak boleh dicantumkan dalam akad yang harus disepakati di awal antara nasabah dan Pegadaian Syariah cabang Blauran.

\section{Penutup}

Berdasarkan hasil penelitian yang dilakukan oleh penulis, berikut ini adalah beberapa kesimpulan dari apa yang telah dipaparkan bahwa Mekanisme penentuan besaran ganti rugi (ta'wid) di Pegadaian Syariah cabang Blauran yaitu:

$$
\frac{4 \% \text { cicilan pokok perbulan } h \text { per bulan }}{30}
$$

Yang harus dibayar oleh nasabah ditambah angsuran per bulan apabila nasabah terlambat membayar angsuran setiap bulan pada jatuh tempo yang telah ditentukan. Dana ta'wid tersebut dipisahkan dengan dana lainnya yang kemudian digunakan untuk Dana Kebajikan Umat (DKU).

Bahwa mekanisme penentuan besaran ganti rugi (ta'wid) tersebut belum sepenuhnya sesuai dengan syarat sahnya ta'wid apabila kerugian yang ditimbulkan bukan karena kerugaian yang riil dan hanya berupa kerugian yang hanya diperkirakan saja sebenarnya tidak tepat untuk dimintai ta'wid,karena kerugian tersebut belum pasti dialami dan belum

30 Yeni Salma Barlinti, Kedudukan Fatwa Dewan Syariah Nasional Dalam Sistem Hukum Nasional Di Indonesia (Jakarta: Badan Litbang Dan Kementrian Agama, 2010).66 
bisa diperhitungkan dengan jelas, sedangkan menurut Fatwa DSN-MUI Nomor 43 Tahun 2004 tentang ta'wid(ganti rugi), praktik tersebut tidak sesuai karena dalam fatwa tersebut tidak diperbolehkan mencantumkan besaran ganti rugi/denda atas kerugian atau kelalaian nasabah, namun pada praktiknya Pegadaian Syariah mencantumkan besaran ganti rugi tersebut di dalam akad yang harus disepakati oleh nasabah yang akan melakukan pembiayaan Arrum Haji di Pegadaian Syariah cabang Blauran.

\section{Daftar Pustaka}

(ISRA), International Shari'ah Research Academy for Islamic Finance. Sistem Keuangan Islam: Prinsip Dan Operasi, Terj. Ellys T. Jakarta: RajaGrafindo Persada, 2015.

Abdullah, Samnur. "Mekanisme Penetapan Ta'widh Di Bank BNI Syariah Pada Produk Hasanah Card." Skripsi S1 FSH UIN Syarif Hidayatullah Jakarta, 2012.

al-Zuhaili, Wahbah. Nazariyah Al-Dhaman. Damsyiq: Dar alFikr, 1998.

Al-Zuhaili, Wahbah, and Adiwarman A. dalam Karim. Maqashid Bisnis Dan Keuangan Islam: Sintesis Fikih Dan Ekonomi. Jakarta: Rajawali Pers, 2016.

Barlinti, Yeni Salma. Kedudukan Fatwa Dewan Syariah Nasional Dalam Sistem Hukum Nasional Di Indonesia. Jakarta: Badan Litbang Dan Kementrian Agama, 2010.

Djazuli, A. Kaidah-Kaidah Fiqih: Kaidah-Kaidah Hukum Islam

Dalam Menyelesaikan Masalah- Masalah Yang Praktis, Cet.1. Jakarta: Kencana, 2006.

Fajar, Mukti. Desain Penelitian Hukum Normatif Dan Empiris. Yogyakarta: Pustaka Pelajar, 2010.

Fokusmedia. Kompilasi Hukum Ekonomi Syariah. Bandung: Fokusmedia, 2008.

Huda, Nurul. Lembaga Keuangan Islam. Jakarta: Kencana, 2013. Imamuddin, Basuni, and Nashiroh Ishaq. Kamus Konstektual Arab-Indonesia. Depok: Gema Insani, 2012.

Indonesia, Departemen Agama Republik. Al-Qur'an Dan Terjemahannya. Bandung: Syamiil al-Qur'an, 2005. Kashiko, Tim. Kamus Lengkap Arab Indonesia. Surabaya: 
Praktik Denda Keterlambatan Pelunasan Produk Pembiayaan Arrum Haji ...

Kashiko, 2000.

Noor, Juliansyah. Metodologi Penelitian. Jakarta: Prenadamedia Group, 2015.

Prastowo, Andi. Metode Penelitian Kualitatif. Yogyakarta: ArRuzz Media, 2014.

Brosur Arrum Haji Pegadaian Syariah, n.d.

Fatwa DSN MUI Nomor 43 Tahun 2004 Tentang Ganti Rugi, n.d. "Https://Pegadaiansyariah.Co.Id/Arrum-Haji-45162."

"Pegadaian Syariah." https://pegadaiansyariah.co.id/.

Wuwuh, Wawancara, (Kantor Cabang Pegadaian Blauran Surabaya), pada tanggal 15 Mei 2019

Hapsari Wijaya, Wawancara, (Kantor Cabang Pegadaian Blauran Surabaya), pada tanggal 15 Mei 2019 